\title{
COMPARISON OF INTEGRAL AND DISCRETE OSTROWSKI'S INEQUALITIES IN THE PLANE
}

\author{
SHINYA MORITOH AND YUMI TANAKA
}

Abstract. A comparison of integral and discrete Ostrowski's inequalities in the plane is considered. An integral inequality is described by Legendre's elliptic integrals. A natural discrete analogue of the inequality is also given. The main point is to find a suitable decomposition of the radius in polar coordinates.

Mathematics subject classification (2010): 26D10, 26D15.

Keywords and phrases: Ostrowski's inequality, discrete analogue.

\section{REFERENCES}

[1] J. DuOANDIKoETXEA, A unified approach to several inequalities involving functions and derivatives, Czechoslovak Math. J. 51 (126) no. 2 (2001), 363-376.

[2] A. Erdélyi, W. Magnus, F. Oberhettinger and F. G. Tricomi, Higher Transcendental Functions, Vol. II, Bateman Manuscript Project, McGraw-Hill Book Company, Inc., New York-TorontoLondon, 1953.

[3] K. FAn, O. TAussky And J. Todd, Discrete analogs of inequalities of Wirtinger, Monatsh. Math. 59 (1955), 73-90.

[4] D. S. Mitrinović, J. E. PeČARIĆ AND A. M. FinK, Inequalities involving functions and their integrals and derivatives, Mathematics and its Applications (East European Series), 53, Kluwer Academic Publishers, Dordrecht, The Netherlands, 1991.

[5] A. OstrowsKI, Über die Absolutabweichung einer differentiierbaren Funktion von ihrem Integralmittelwert, Comment. Math. Helv. 10 (1) (1938), 226-227.

[6] G. PóLYA, Ein Mittelwertsatz, für Funktionen mehrerer Veränderlichen, Tôhoku Math. J. 19 (1921), $1-3$.

[7] G. Pólya, Collected Papers, Vol. III. Analysis, Edited by J. Hersch, G.-C. Rota, M. C. Reynolds and R. M. Shortt, MIT Press, Cambridge, MA, 1984.

[8] L. A. SAnTaló, Integral Geometry and Geometric Probability, With a Foreword by Mark Kac, Encyclopedia of Mathematics and its Applications Vol. 1, Addison-Wesley Publishing Co., Reading, Mass.-London-Amsterdam, 1976.

[9] C. Tricot, Curves and Fractal Dimension, With a Foreword by Michel Mendès France, Translated from the 1993 French original, Springer-Verlag, New York, 1995. 